Ambiente \& Água - An Interdisciplinary Journal of Applied Science
ISSN 1980-993X - doi:10.4136/1980-993X
www.ambi-agua.net
E-mail: ambi.agua@gmail.com

\title{
Rapid method for determination of glyphosate in groundwater using high performance liquid chromatography and solid-phase extraction after derivatization
}

\author{
doi: 10.4136/ambi-agua.1548
}

Received: 18 Oct. 2014; Accepted: 18 Dec. 2014

\author{
Valdir Eduardo Olivo ${ }^{1}$; Andréia Tansini ${ }^{1}$; Fábio Carasek $^{1}$; Dórys Cordenuzzi $^{1}$; Suellen \\ Fernandes $^{1}$; Marcio Antônio Fiori ${ }^{1}$; Alex Fragoso ${ }^{2}$; Jacir Dal Magro ${ }^{1 *}$ \\ ${ }^{1}$ Universidade Comunitária da Região de Chapecó (UNOCHAPECO), Chapecó, SC, Brasil \\ Programa de Pós-Graduação em Ciências Ambientais \\ ${ }^{2}$ Universitat Rovira i Virgili (URV), Països Catalans, 26, Tarragona 43007, Espanha \\ Departament d'Enginyeria Química \\ *Corresponding author: e-mail: jacir@unochapeco.edu.br, \\ eduardo@baseamb.com.br, andreiata@unochapeco.edu.br, fabio_carasek@hotmail.com, \\ dorys@unochapeco.edu.br, suellencf@unochapeco.edu.br, fiori@unochapeco.edu.br, \\ alex.fragoso@urv.cat
}

\begin{abstract}
The intensive use of pesticides in agriculture has prompted researchers to develop new methods for identifying these pollutants in water. This study sought to validate a high performance liquid chromatography (HPLC) method to determine the concentration of the pesticide glyphosate in groundwater samples by using solid-phase extraction (SPE) filters after derivatization with chloroformate 9-fluorenylmethoxycarbonyl (FMOC-Cl). For the HPLC method, we evaluated the following main validation parameters: linearity, specificity, precision, accuracy, robustness, and limits of detection and quantification. After validation of the method, we determined the concentration of glyphosate in samples from thirteen deep, tubular wells distributed in urban and rural areas in Chapecó, SC, Brazil. The solvent used in the extraction of excess FMOC-Cl was dichloromethane and subsequently filtration was performed on C18 SPE, and injected into the chromatograph column in amino polymer with fluorescence detection. The analytical curve made in ultrapure water was linear, with a correlation coefficient of 0.99 . The limits of detection and quantification were 0.24 and $0.07 \mu \mathrm{g} \mathrm{L}^{-1}$, respectively. Recovery tests in natural waters ranged from 90.37 to $101.70 \%$. Glyphosate was detected in 5 of the thirteen wells evaluated. The highest concentration of glyphosate $\left(6.80 \mu \mathrm{g} \mathrm{L}^{-1}\right)$ was detected in a countryside well, near the municipal water supply. Despite the low levels of glyphosate detected in our study, any amount present in groundwater samples is worrisome, as these molecules have low ground mobility.
\end{abstract}

Keywords: agriculture, chromatographic method, pesticides. 


\section{Método rápido para determinação de glifosato em água subterrânea usando cromatografia líquida de alta eficiência e extração em fase sólida após derivatização}

\section{RESUMO}

O uso intensivo de agrotóxicos na agricultura alerta os pesquisadores a desenvolverem novos métodos de identificação destes poluentes em amostras de água. Este estudo teve como objetivo validar um método por cromatografia líquida de alta eficiência (CLAE) para determinar o agrotóxico glifosato em amostras de águas subterrâneas utilizando filtros de extração em fase sólida (SPE) após derivatização com cloroformato de 9-fluorenilmetoxicarbonil (FMOC-Cl). Para o método em CLAE, foram avaliados os principais parâmetros de validação: linearidade, especificidade, precisão, exatidão, robustez, limites de detecção e quantificação. Após validação do método foi determinada a concentração de glifosato em amostras de 13 poços tubulares profundos distribuídos na área urbana e rural no município de Chapecó, SC, Brasil. O solvente utilizado na extração do FMOC-Cl em excesso foi o diclorometano, posteriormente foi realizada filtragem em SPE C18 e injeção no cromatógrafo em coluna polimérica amino com detecção por fluorescência A curva analítica realizada em água ultrapura apresentou linearidade com coeficiente de correlação de 0,99 . Os limites de quantificação e detecção foram de 0,24 e $0,07 \mu \mathrm{g} \mathrm{L}^{-1}$, respectivamente. Os testes de recuperação em águas naturais variaram de 90,37 a 101,70 \%. Dos 13 poços avaliados o glifosato foi detectado em cinco, sendo que a maior concentração de glifosato encontrada foi de $6,80 \mu \mathrm{g} \mathrm{L}^{-1}$ em um poço localizado na zona rural, próximo à nascente de abastecimento do município. Apesar dos baixos níveis de glifosato detectados em nossa pesquisa, é preocupante o aparecimento destas moléculas em amostras de águas subterrâneas considerando a baixa mobilidade desta molécula no solo.

Palavras-chave: agricultura, método cromatográfico, pesticidas.

\section{INTRODUCTION}

In 2012, herbicides were the second largest group of pesticides sold globally (Sindiveg, 2012). Among them, the primary and most popularly used is glyphosate [N-(phosphonomethyl) glycine], $\mathrm{C}_{3} \mathrm{H}_{8} \mathrm{NO}_{5} \mathrm{P}$. This powerful agrochemical is used to kill weeds that harm agricultural production, and its deleterious effects on the environment are evident in both aquatic and terrestrial ecosystems, as well as in humans (Amarante Jr. et al., 2002; Pinheiro et al., 2011).

Glyphosate is relatively small in size and has three polar functional groups: carboxyl, amino and phosphonate. The agrochemical has a long half-life, ranging from 49 to 70 days in water, which makes it persistent in soil. High solubility in water $\left(12.000 \mathrm{mg} \mathrm{L}^{-1}\right)$ assists in the transport of glyphosate from terrestrial to aquatic environments. These molecules can be transported to both surface and groundwater, although groundwater samples have not been extensively investigated by the scientific community (Sanchís et al., 2011).

Glyphosate has low acute toxicity to animals because its biochemical mode of action negatively affects shikimic acid, which is found in plants but not in animals (Mirande et al., 2010).

According to data from SINDAG (National Union of Agricultural Products Industry), Brazil leads the world in herbicide and insecticide usage, and the western region of Santa Catarina State has extensive agricultural production in areas that permeate urban centers; this, along with the fact that margin strips of streams and springs are often not respected, causes these chemical compounds to spread easily to aquatic environments. Glyphosate also has 
relatively low cost and high efficiency, which results in wide agricultural application. The possibility of resulting environmental contamination must be studied carefully, as there is evidence of harmful environmental effects after prolonged use (Souza et al., 2006).

There are various techniques for determination of glyphosate in environmental samples; however, its high solubility in water, insolubility in organic solvents and low volatility present analytical challenges (Hsu and Whang, 2009). Glyphosate also has high polarity and lacks a chromophore. Detection methods thus require adaptations utilizing derivatization reactions or alteration of some physical property that can be correlated to the amount of glyphosate in the sample (See et al., 2010).

Among the methods used by various authors, the most commonly used derivatization method involves use of FMOC-Cl (9-fluorenylmethyl chloroformate). High fluorescence derivatives can be formed by pre- or post-column derivatization with FMOC-Cl or mercaptoethanol ortho-phthalaldehyde (OPA), respectively (Nedelkoska and Low, 2004). FMOC-Cl can be used for derivatization for both primary and secondary amino groups, and unlike the post-column derivatization, there are no restrictions for mobile phase composition, and the derivation reaction can be better controlled outside of the column (Ghanem et al., 2007).

The Environmental Protection Agency (EPA) recommends technical HPLC with fluorescence detection for analysis of glyphosate, after undergoing column derivatization (USEPA, 2013). However, the pre-column derivatization technique based on 9-fluorenylmethyl chloroformate is currently being employed due to its speed and high sensitivity (Sanchís et al., 2011). To derive allies with this reagent, it is common to use solid phase extraction (SPE) cartridges. Chromatography instruments are used for retention of impurities, filtration processes and analysis. C-18 cartridges are used for extraction of hydrophobic or polar organic analytes in aqueous matrices.

The objectives of this study were (i) to validate the analytical method for rapid determination of glyphosate concentration in groundwater samples, (ii) to optimize the conditions for derivatization of glyphosate, applying SPE to increase the sensitivity of the method and (iii) to test the applicability of the proposed method by evaluating the presence of glyphosate in groundwater samples in Chapecó, SC, Brazil.

\section{MATERIALS AND METHODS}

\subsection{Reagents}

Glyphosate (purity 99.5\%) was obtained from Chem Service (USA); HPLC grade acetonitrile was obtained from JT Baker (Mexico); and 9-fluorenylmethyl chloroformate (FMOC-Cl), potassium phosphate monobasic, potassium hydroxide (KOH), sodium tetraborate decahydrate and dichloromethane (Chromasolv Plus, 99.9\% purity HPLC grade) were purchased from Sigma-Aldrich.

Borate buffer, $\mathrm{pH} 9(0.125 \mathrm{M})$, was prepared with de-ionized water and $\mathrm{pH}$ was adjusted with $\mathrm{KOH}(6 \mathrm{M})$. The FMOC-Cl $(0.005 \mathrm{M})$ solution was prepared by dissolving the reagent in acetonitrile. A standard glyphosate solution $\left(1000 \mathrm{mg} \mathrm{L}^{-1}\right)$ was prepared, which was then used to prepare another standard solution of $1 \mathrm{mg} \mathrm{L}^{-1}$. Dilutions were made to cover the range of 5 to $25 \mu \mathrm{g} \mathrm{L}^{-1}$, all prepared with de-ionized water in polypropylene bottles to prevent any loss of glyphosate on glass surfaces. In this study, we used detection in $\mu \mathrm{g} \mathrm{L}^{-1}$. Water was de-ionized using the Milli-Q system (Millipore, USA). The mobile phase consisted of acetonitrile and phosphate buffer at $\mathrm{pH} 10,(60: 40, \mathrm{v} / \mathrm{v})$. $\mathrm{pH}$ was adjusted with $6 \mathrm{M} \mathrm{KOH}$. Figure 1 illustrates the process from sample preparation to liquid chromatography measurement. 


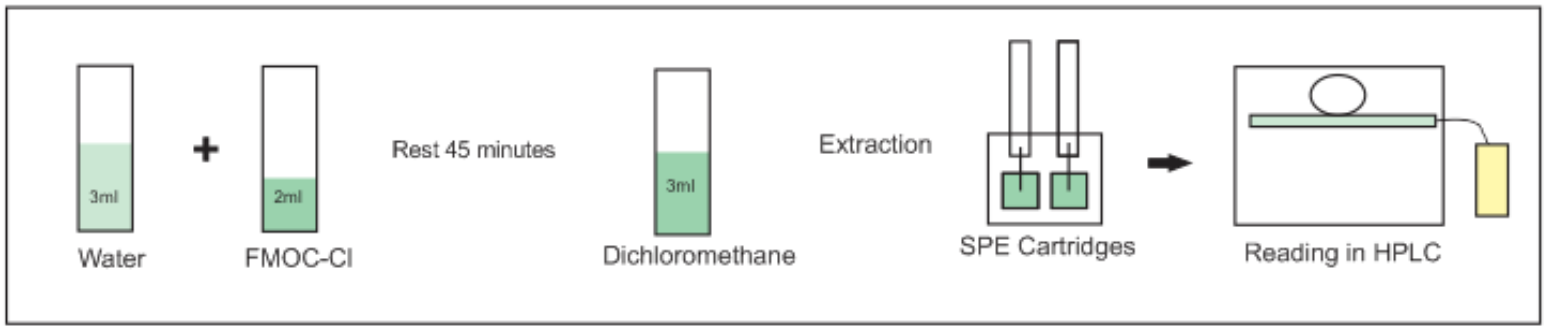

Figure 1. Sample preparation scheme for HPLC.

\subsection{Equipment}

The following equipment was used:

- HPLC ProStar 210/215 SDM 270VA. ProStar 410 Autosampler 200VA. ProStar 360 Fluorescence detector $200 \mathrm{VA}$.

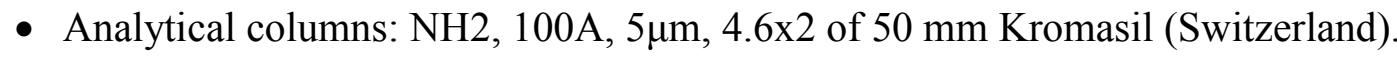

- Ultrasound Sonicator Ultra Cleaner 1400 of Unique (Brazil).

- C-18 SPE cartridge and Strata-55um, 70A from Phenomenex (Brazil).

\subsection{Validation Method}

We used the ANVISA (Brazil) guide to validate analytical and bioanalytical methods. This guide classifies our tests as Class 1. The following tests were performed: specificity, linearity, range, accuracy, repeatability, accuracy, robustness, limit of quantification and detection limit.

The determination of the calibration curve for glyphosate was performed using a polymeric amino column, with the mobile phase consisting of acetonitrile and phosphate buffer $(60: 40 \mathrm{v} / \mathrm{v})$. The flow of the mobile phase was $0.7 \mathrm{~mL} \mathrm{~min}^{-1}$, with isocratic method at room temperature. Fluorescence detection was set at a wavelength of $266 \mathrm{~nm}$ extinction and $315 \mathrm{~nm}$ emission, with a run time of 10 minutes.

The samples were prepared with de-ionized water, with different glyphosate aliquots ( 5 to $25 \mu \mathrm{g} \mathrm{L}^{-1}$ ) to obtain the required concentrations. The total volume per concentration was brought up to $5 \mathrm{~mL}$, after which $0.5 \mathrm{~mL}$ of borate buffer was added to maintain alkaline $\mathrm{pH}$.

Derivatization occurred with the addition of $2 \mathrm{~mL}$ of FMOC-Cl $(0.005 \mathrm{M})$. To avoid FMOC-Cl precipitation, a volume of water was added prior to reagent addition. The reaction was maintained at room temperature for the following reaction times: 30,45 and 60 minutes. The excess FMOC-Cl was removed by extraction with $3 \mathrm{~mL}$ of dichloromethane, and the end of the supernatant was filtered using a SPE cartridge prior to injection into the HPLC column, as described in Section 2.5.

Specificity/selectivity: they were observed with the standard chromatogram and a sample analysis without glyphosate (blank). To secure and to avoid interference from other compounds in the sample, tests were conducted by passing samples of only water, buffer, FMOC-Cl and the mobile phase through the column, thus ensuring that the interfering peaks cannot be glyphosate.

Precision: it was evaluated through repeatability. It was determined by preparation, under the same conditions, of 9 analytical solutions of the sample at working concentration. Relative standard deviation (RSD) was considered acceptable, according to resolution 899/2003 ANVISA (Brasil, 2003).

Accuracy: it was assessed based on the degree of recovery, expressed as percentage of glyphosate solutions fortified with known amounts of glyphosate in triplicate, determined by the ratio between the experimental and theoretical average concentrations using Equation 1: 


$$
\text { Accuracy }=\frac{\text { Experimental average concentration }}{\text { Theoretical average concentration }} \times 100
$$

Robustness: Tests for robustness were performed with slight variations in the analytical parameters, including the variation in mobile phase, mobile phase composition, temperature, and flow rate.

\subsection{Groundwater analyses}

After validation of analytical methods, samples were taken from deep wells within the boundaries of Chapecó, Brazil. Thirteen wells were chosen, and some points are located in a rural area with strong agricultural influence. The coordinates described herein are depicted in the UTM system WGS 84 22J area (Figure 2).

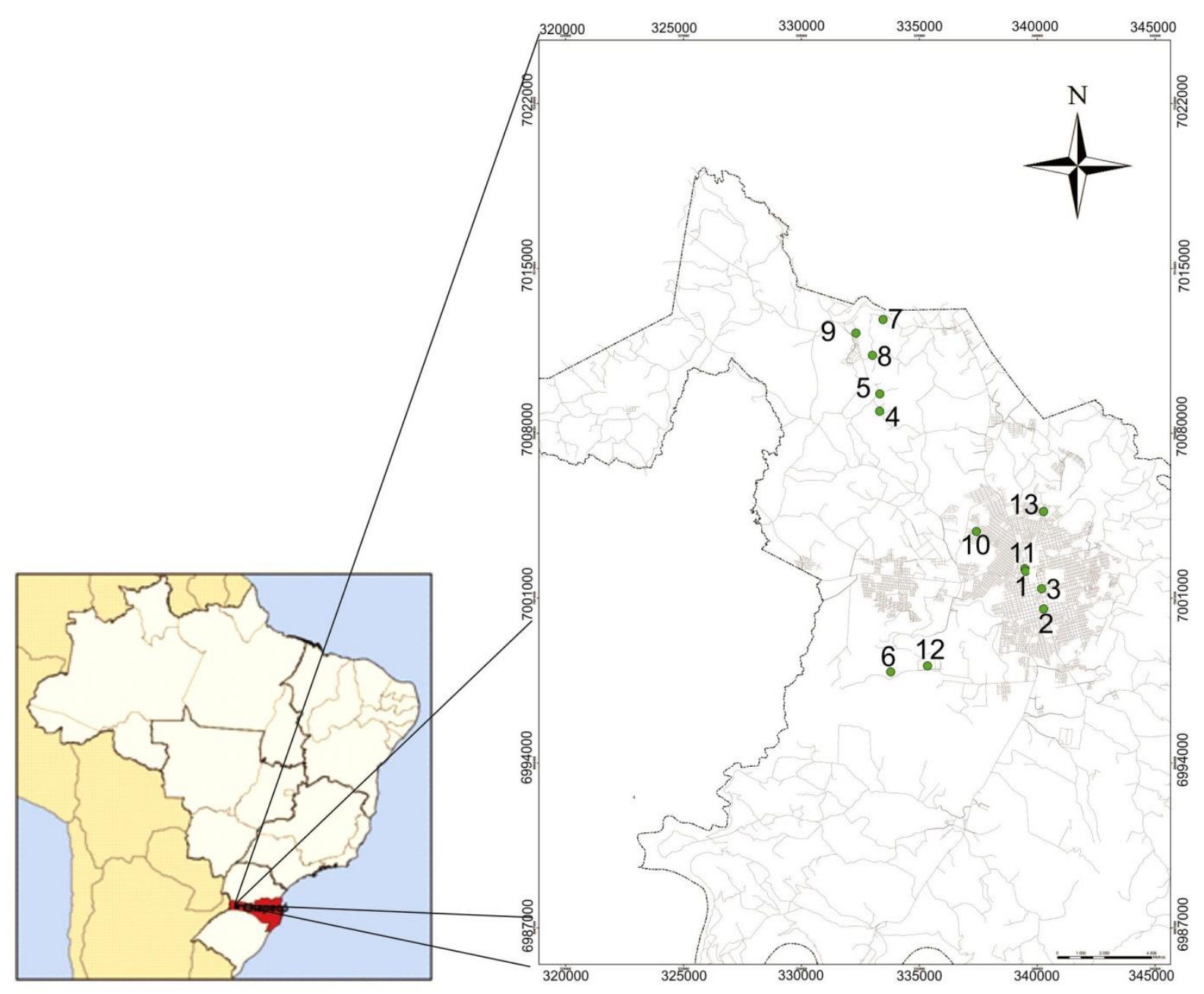

Figure 2. Geographical locations of water samples.

\subsection{SPE cartridge extraction}

The cartridge sorbent material is first activated by passing an appropriate solvent through to condition the solid surface (in this case water). The dichloromethane extraction supernatant is subsequently passed through the cartridge. At this stage, the unreacted FMOC-Cl from the dichloromethane extraction is retained on the stationary phase, allowing passage of the more polar derivatized glyphosate (Figure 3). After this step, washing tests with different volumes 
of water $(1,2$ and $3 \mathrm{~mL})$ were performed to determine the optimal volume. The optimal volume found was $1 \mathrm{~mL}$ of water to washing cartridges.

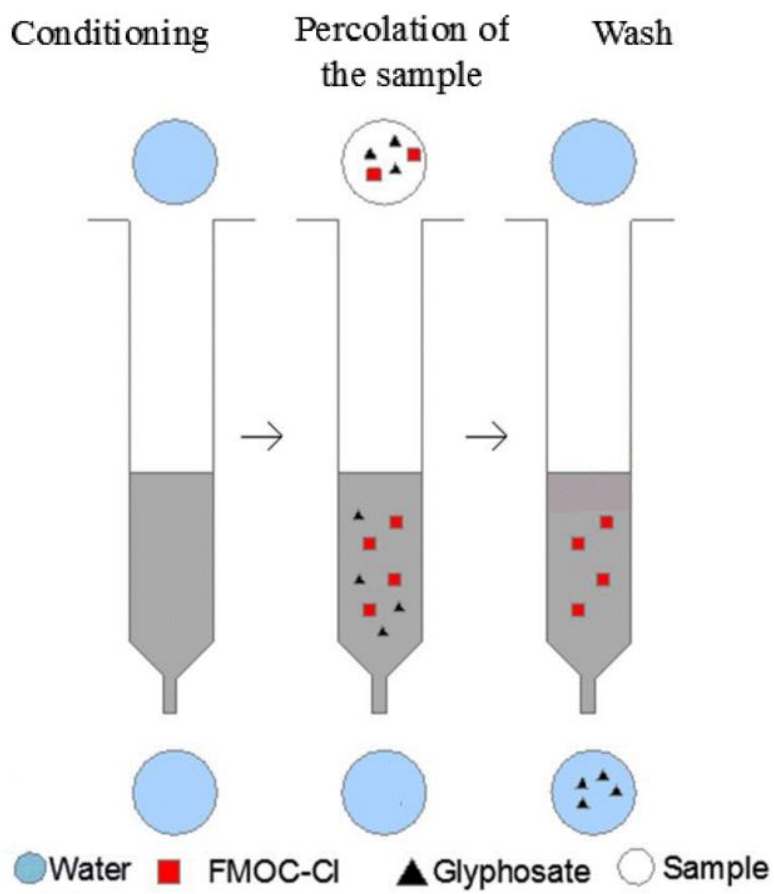

Figure 3. SPE cartridge extraction overview.

\section{RESULTS AND DISCUSSION}

\subsection{Glyphosate chromatograms}

Figure 4 shows the chromatograms of the analyses initially with ultrapure water, known as white, and without (a) and with (b) the use of the cartridge. Samples fortified at a concentration of $5 \mu \mathrm{g} \mathrm{L}^{-1}$ presented a chromatogram peak time of 6.5 minutes. In (c) the glyphosate peak becomes partially covered by FMOC-Cl reagent around 3 minutes. In (d) the chromatogram is clean and well-defined due to the use of SPE cartridges.
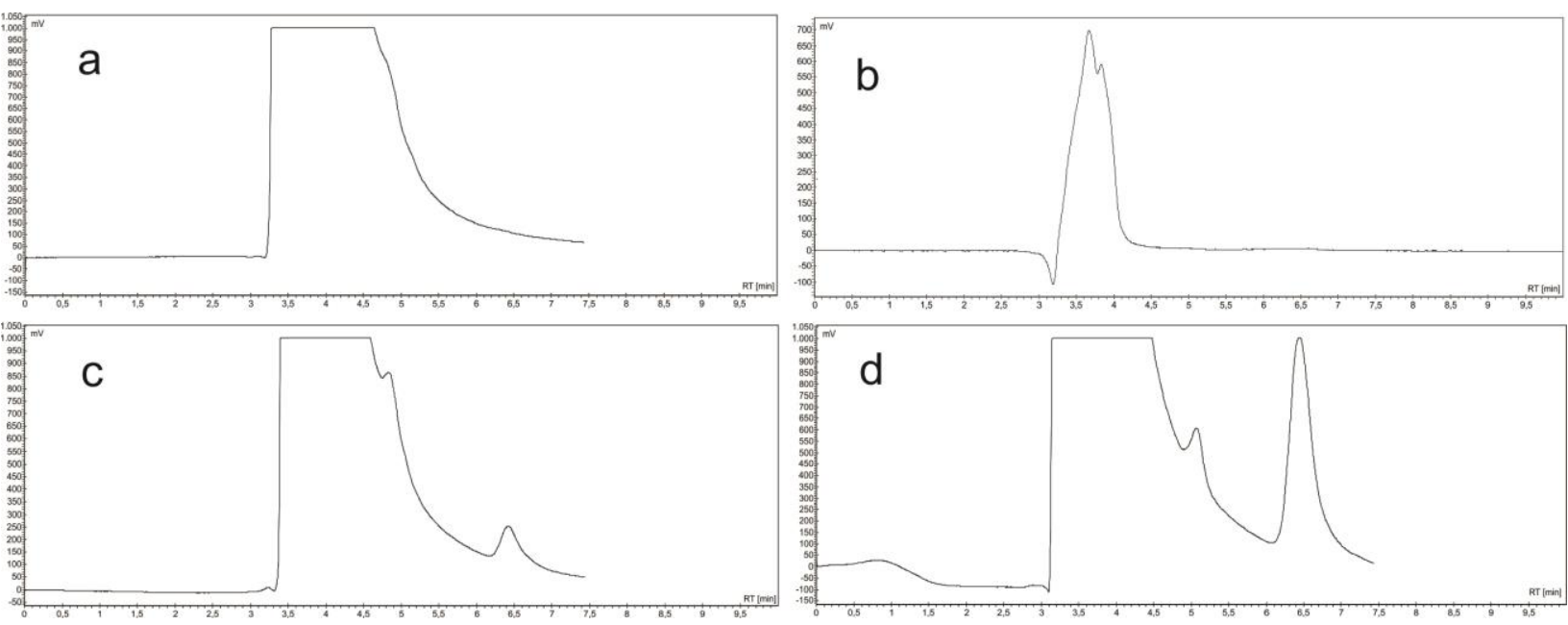

Figure 4. Chromatograms of real and white analyses with and without SPE cartridge use. (a) Ultrapure water (white) without use of the cartridge, (b) ultrapure water (white) with use of the cartridge, (c) glyphosate $\left(5 \mu \mathrm{g} \mathrm{L}^{-1}\right)$ partially covered by FMOC-Cl and (d) glyphosate $\left(5 \mu \mathrm{g} \mathrm{L}^{-1}\right)$ with use of SPE cartridges. 


\subsection{Specificity and selectivity}

The method used to specificity and selectivity of the analysis was specific and selective for glyphosate through comparative analysis of chromatogram with the standard and with a sample analysis without glyphosate (blank); we did not observe any interference in the analyses.

\subsection{Linearity of the calibration curve}

Linearity analysis of our five different concentrations of analytes resulted in a correlation coefficient (R) of greater than 0.999 for all sample concentrations. ANVISA (Brasil, 2003) recommends a correlation coefficient of 0.99 . This coefficient demonstrates that the detector response was linear for the range of concentrations used (Figure 5).

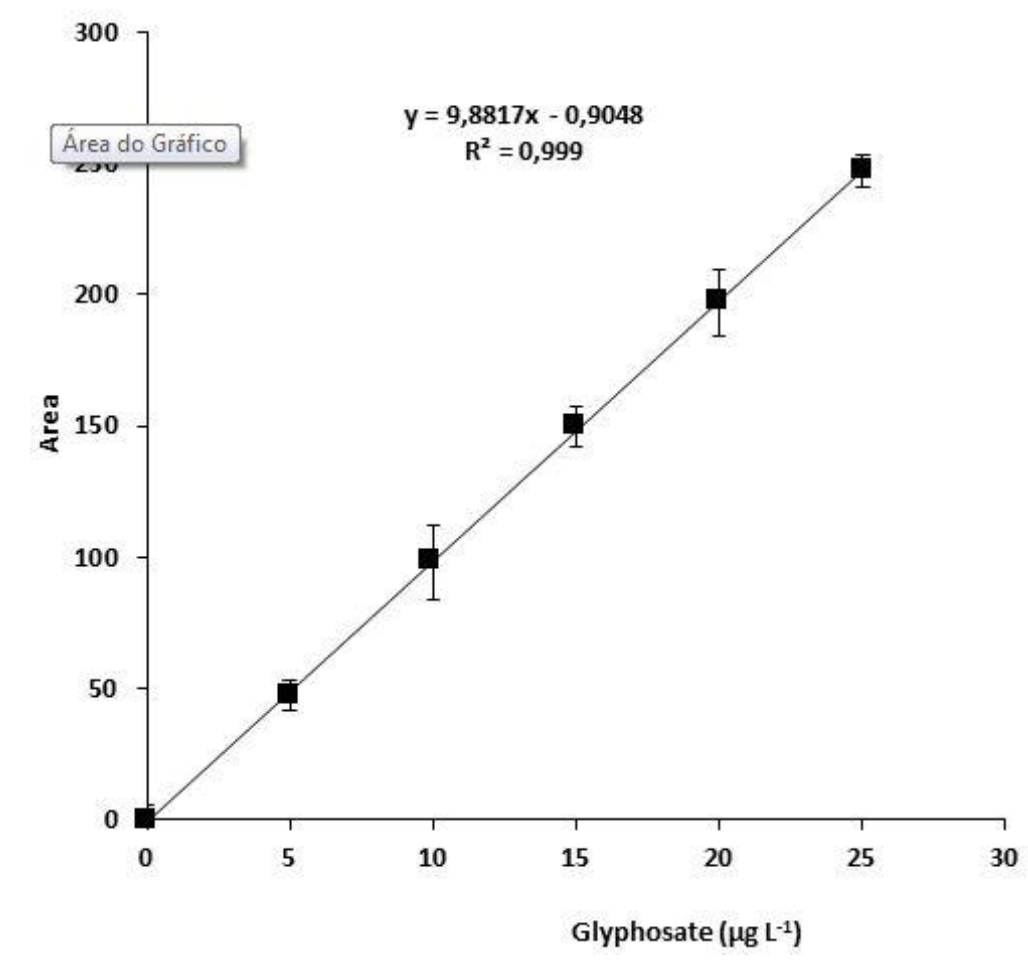

Figure 5. Analytical curve for glyphosate, the error bars indicate \pm 1 standard deviation.

\subsection{Precision}

To test repeatability, three replicates were performed each for low, medium and high concentrations $\left(5 \mu \mathrm{g} \mathrm{L}^{-1}, 15 \mu \mathrm{g} \mathrm{L}^{-1}\right.$ and $\left.25 \mu \mathrm{g} \mathrm{L}^{-1}\right)$ (Table 1).

Table 1. Data obtained from the precision assay.

\begin{tabular}{ccccc}
\hline $\begin{array}{c}\text { Concentration } \\
\left(\mu \mathrm{g} \mathrm{L}^{-1}\right)\end{array}$ & $\begin{array}{c}\text { Retrieved Concentration } \\
\left(\mu \mathrm{g} \mathrm{L}^{-1}\right)\end{array}$ & Average & $\begin{array}{c}\text { Standard } \\
\text { Deviation }\end{array}$ & RSD (\%) \\
\hline \multirow{2}{*}{5} & $\begin{array}{c}4.9803 \\
5.0059\end{array}$ & 4.7788 & 0.3713 & 7.7 \\
& $\begin{array}{c}\text { 4.3503 } \\
14.4021\end{array}$ & & & \\
& 13.1521 & 14.1865 & 0.9453 & 6.6 \\
15 & 15.0054 & & & \\
& 24.9523 & & & \\
& 25.8875 & 25.4325 & 0.4681 & \\
\hline
\end{tabular}

Rev. Ambient. Água vol. 10 n. 2 Taubaté - Apr. / Jun. 2015 
Considering data obtained from the nine analytical solutions prepared, the method demonstrated repeatability with a relative standard deviation (RSD\%) of up to $7.7 \%$ among samples prepared on the same day under the same conditions, within the maximum permitted by applicable law (Brasil, 2003).

\subsection{Limits of detection and quantification}

Limits of Detection (LD) and Limits of Quantification (LQ) were estimated using the standard deviation (SD) of the intercept and the value of the slope (SC) of the calibration curve according to Equations 2 and 3:

$$
\begin{aligned}
& L D=\frac{S D \times 3.3}{S C} \\
& L Q=\frac{S D \times 10}{S C}
\end{aligned}
$$

The limits of detection and quantification obtained in this study are shown in Table 2.

\begin{tabular}{|c|c|c|}
\hline & $\begin{array}{c}\text { Limit of Detection } \\
\qquad\left(\mu \mathrm{g} \mathrm{L^{-1 } )}\right.\end{array}$ & $\begin{array}{c}\text { Limit of Quantification } \\
\qquad\left(\mu \mathrm{g} \mathrm{L^{-1 } )}\right.\end{array}$ \\
\hline Water Sample & 0.07 & 0.24 \\
\hline
\end{tabular}

Table 2. Data obtained for limits of detection and quantification.

Sanchís et al. (2011) identified in their studies limits of detection and quantification of up to 3.2 and $9.6 \mathrm{ng} \mathrm{L}^{-1}$, respectively, for glyphosate samples using SPE cartridge extraction methods, but with linearity (R) less than 0.98. Considering the maximum allowed under current Brazilian environmental legislation $\left(500 \mu \mathrm{g} \mathrm{L}^{-1}\right)$, these values were considered satisfactory.

\subsection{Accuracy}

The results for accuracy at concentrations of 5, 15 and $25 \mu \mathrm{g} \mathrm{L}{ }^{-1}$ showed a mean recovery percentage of between $90.37 \%$ and $101.79 \%$ (Table 3 ).

Table 3. Glyphosate recovery in water samples.

\begin{tabular}{cccc}
\hline & $\mathbf{5} \boldsymbol{\mu} \mathbf{g ~ \mathbf { L } ^ { - 1 }}$ & $\mathbf{1 5} \boldsymbol{\mu g} \mathbf{~ L}^{-1}$ & $\mathbf{2 5} \boldsymbol{\mu} \mathbf{g ~ \mathbf { ~ L } ^ { - 1 }}$ \\
\hline Water sample & $95.53 \%$ & $90.37 \%$ & $101.79 \%$ \\
\hline
\end{tabular}

Recovery was within the acceptable limits of $80-120 \%$ (Brasil, 2003), indicating that the method used is appropriate for the analysis of glyphosate in water.

\subsection{Robustness}

The same sample with slight variations in the analytical parameters (i.e., mobile phase $\mathrm{pH}$, mobile phase composition, temperature, and flow rate) revealed significant variations in the robustness test results. The optimum $\mathrm{pH}$ was 10 and the optimal mobile phase composition ratio was 60:40 acetonitrile:phosphate buffer, as described by Nedelkoska and Low (2004).

\subsection{Derivatization}

Figure 6 depicts the derivatization reaction of glyphosate in $\mathrm{pH} 9$ reagent with FMOC-Cl. This reaction is an aminolysis reaction, in which the acyl chloride (FMOC-Cl) reacts with the secondary amine (glyphosate), producing the corresponding amide (FMOC-glyphosate). The alkaline sequestrant acts as proton-maintaining balanced reaction to the right, through the use of the co-product $\mathrm{HCl}$. In the case of the reaction being performed in acidic or neutral $\mathrm{pH}$, 
released $\mathrm{HCl}$ consumes the rest of the amine group of glyphosate by protonation, causing it to lose group nucleophilicity and decreasing the reaction yield.

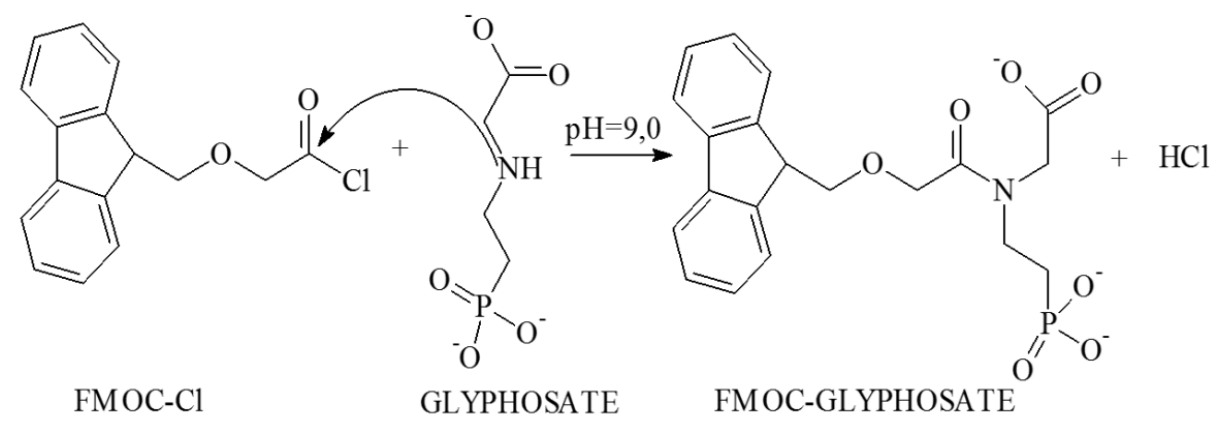

Figure 6. Reaction between FMOC-Cl and glyphosate.

Test trials with different glyphosate derivatization times with FMOC-Cl were performed. Trials were performed with 30,45 and 60 minutes of derivatization in a concentration of $10 \mu \mathrm{g} \mathrm{L}^{-1}$. Increased reaction time resulted in an increase in peak area; however, this increase was not significant after 45 minutes (Table 4).

Table 4. Results of peak area in relation to the reaction time for derivatization.

\begin{tabular}{cc}
\hline Time $\left(\mathrm{min}^{-1}\right)$ & Peak area \\
\hline 30 & $27.67 \pm 1.78^{\mathrm{a}}$ \\
45 & $94.37 \pm 2.91^{\mathrm{b}}$ \\
60 & $91.03 \pm 3.11^{\mathrm{b}}$ \\
\hline
\end{tabular}

Values followed by the same letter in columns do not differ by Tukey test at $95 \%$ confidence level.

\subsection{Determination of glyphosate in water samples}

For the determination of glyphosate in groundwater samples, the same procedures from the analysis method validation guide were used. Glyphosate was detected in five of the thirteen samples tested in low concentrations (Table 5).

Table 5. Glyphosate concentration in groundwater samples.

\begin{tabular}{cc}
\hline Location & $\begin{array}{c}\text { Glyphosate } \\
\left(\mu \mathrm{g} \mathrm{L}^{-1}\right)\end{array}$ \\
\hline Point 1 & 0.2459 \\
Point 2 & 0.4475 \\
Point 3 & 0.0000 \\
Point 4 & 0.0000 \\
Point 5 & 0.0000 \\
Point 6 & 0.0000 \\
Point 7 & 0.4475 \\
Point 8 & 6.7972 \\
Point 9 & 0.0000 \\
Point 10 & 1.5158 \\
Point 11 & 0.0000 \\
Point 12 & 0.0000 \\
Point 13 & 0.0000 \\
\hline
\end{tabular}


According to chromatogram analyses, the highest concentrations of glyphosate were found in sample Sections 8 and 10, both of which are located in agricultural areas. Section 8 is located near the source of the São José watershed, which supplies water to the population of Chapecó.

Current Brazilian legislation (Brasil, 2011) establishes a maximum allowable value (MAV) for glyphosate of $500 \mathrm{mg} \mathrm{L}^{-1}$ in post-treatment samples. According to Item 6 of the same ordinance, detection of pesticides in samples above the MAV should be analyzed in conjunction with the historical control of water quality.

CONAMA Resolution No. 357 established on March 17, 2005 (Brazilian law) provides for the classification of water bodies and creation of environmental guidelines for its framework, and establishes the conditions and standards for effluent discharge. Rivers are in Classes 1 and 3, wherein acceptable levels of glyphosate are $65 \mathrm{mg} \mathrm{L}^{-1}$ and $280 \mathrm{mg} \mathrm{L}^{-1}$ respectively. Our values for groundwater samples are thus well below the limits established by law.

The methods presented in this study have a few advantages over traditional methods. First, very low levels of glyphosate can be detected in water (i.e., sensitivity is higher). The cost is also lower, because the reagents are inexpensive and easily prepared. Efficiency is higher and time expenditure is reduced, because the sample is prepared for reading in a shorter amount of time. This facilitates the analysis of greater numbers of samples compared to other methods.

Despite the low levels of glyphosate detected, detection of any amount of this substance in groundwater samples is worrisome. This is because glyphosate is not easily leached and has rapid adsorption to soil, and is therefore unlikely to contaminate groundwater (Amarante Jr. et al., 2002). The pesticide has rarely been detected in water samples; but in general, this is due to the difficulty of separating the compound, as well as a paucity of studies due to lack of concern (i.e., because the substance is not considered a serious water contaminant).

Glyphosate is a highly polar compound, requiring extraction from aqueous samples with metallic cations and inorganic anions, which can be difficult. If chromophore groups are contained, glyphosate does not absorb visible electromagnetic radiation, and thus can only be detected by fluorescence or colorimetric methods indirectly, or by derivatization (Amarante Jr. et al., 2002).

These results reinforce the importance of more stringent legislation regarding permissible levels of pesticides in water. Current legislation also does not provide guidance for monitoring of synergistic outcomes of agrochemicals, which we think should be considered. This is important because dozens of compounds can be used in farming, and combinations of compounds may form byproducts or produce synergistic effects that are harmful to both humans and ecosystem health.

\section{CONCLUSION}

The use of pesticides in agricultural practices, particularly glyphosate, raises concerns about surface and groundwater quality. Newer methods with greater accuracy and sensitivity should be developed in order to quantify contaminants at low concentrations. Liquid chromatography using solid phase extraction after derivatization with $\mathrm{FMOC}-\mathrm{Cl}$ was effective for the detection of glyphosate in water, and allows greater sensitivity for quantification of glyphosate in parts per billion ( $\mathrm{ppb}$ ). Our trials measuring glyphosate levels in groundwater in urban and rural areas of Chapecó found concentrations within the limits permitted by law; but their presence in rural areas confirms widespread use of this compound, which may affect the water quality in the municipality. Our study suggests that further research should be 
conducted to analyze groundwater glyphosate in this region in order to aid in the protection of the regional ecosystem and preservation of water supply quality.

\section{ACKNOWLEDGEMENTS}

The authors thank CAPES, FAPESC and Research Project Rede Guarani Serra Geral (CTHidro/ANA/ CNPq/ FAPESC) for their financial support.

\section{REFERENCES}

AMARANTE JUNIOR, O. P. et. al. Glifosato: propriedades, toxicidade, usos e legislação. Química Nova, v. 25, n. 4, p. 589-593, 2002. http://dx.doi.org/10.1590/S010040422002000400014

BRASIL. Agência Nacional de Vigilância Sanitária - ANVISA. Resolução n. 899 de 29 de Maio de 2003. Available in:

$<$ http://www.anvisa.gov.br/legis/resol/2003/re/899_03rehtm>. Access in May 2014.

BRASIL. Agência Nacional de Vigilância Sanitária - ANVISA. Portaria n. 2914 de 12 de dezembro de 2011. Available in:

$<$ http://bvsms.saude.gov.br/bvs/saudelegis/gm/2011/prt2914_12_12_2011.html >. Access in September 2014.

GHANEM, A.; BADOS, P.; KERHOAS, L.; DUBROCA, J.; EINHHORN, J. Glyphosate and AMPA Analysis in Sewage Sludge by LC-ESI-MS/MS after FMOC Derivatization on Strong Anion-Exchange Resin as Solid Support. Analytical Chemistry, v. 79, n. 10, p. 3794-3801, 2007. http://dx.doi.org/10.1021/ac062195k

HSU, C. C.; WHANG, C. W. Microscale solid phase extraction of glyphosate and aminomethylphosphonic acid in water and guava fruit extract using alumina-coated iron oxide nanoparticles followed by capillary electrophoresis and electrochemiluminescence detection. Journal of Chromatography A. v. 1216, n. 49, p. 8575-8580, 2009. http://dx.doi.org/10.1016/j.chroma.2009.10.023

MIRANDE, L.; HARAMBOURE, M.; SMAGGHE, G.; PINEDA, S.; SCHNEIDER, M. I. Side-effects of glyphosate on the life parameters of eriopis connexa (coleoptera: coccinelidae) in Argentina. Communications in Agricultural and Applied Biological Sciences, v.75, n. 3, p. 367-372, 2010.

NEDELKOSKA, T. V.; LOW, G.K-C. High-performance liquid chromatographic determination of glyphosate in water and plant material after pre-column derivatisation with 9-fluorenylmethyl chloroformate. Analytica Chimica Acta, v. 511, p. 145-153, 2004. http://dx.doi.org/10.1016/j.aca.2004.01.027

PINHEIRO, A.; KAUFMANN, V.; QUEIROZ, G. M. P.; DA SILVA, M. R.; BIANCO, R. J. F. Transporte de glifosato pelo escoamento superficial e por lixiviação em um solo agrícola. Química Nova, v. 34, n. 2, p. 190-195, 2011. http://dx.doi.org/10.1590/S010040422011000200004 
SANCHÍS, J.; KANTIANI, L.; LLORCA, M.; RUBIO, F.; GINEBREDA, A.; FRAILE, J. et al. Determination of glyphosate in groundwater samples using an ultrasensitive immunoassay and confirmation by on-line solid-phase extraction followed by liquid chromatography coupled to tandem mass spectrometry. Analytical And Bioanalytical Chemistry, v. 402, n. 7, p. 2335-2345, 2011. http://dx.doi.org/10.1007/s00216-0115541-y

SEE, H. H.; HAUSER, P. C.; IBRAHIM, W. A. V.; SANAGI, M. M. Rapid and direct determination of glyphosate, glufosinate and aminophosphonic acid by online preconcentration CE with conductivity detection. Electrophoresis, v. 31, p. 575-582, 2010. http://dx.doi.org/10.1002/elps.200900380

SINDICATO NACIONAL DA INDÚSTRIA DE PRODUTOS PARA A DEFESA VEGETAL - SINDIVEG. Estatísticas do setor. 2012. Available in $<$ http://www.sindiveg.org.br/estatisticas.php $>$. Access in May 2014.

SOUZA, T. A.; MATTA, M. H. R.; MONTAGNER, E.; ABREU, A. B. E. Estudo da recuperação de glifosato e AMPA, derivados em solo utilizando-se resinas nacionais. Química Nova, v. 29, n. 6, p. 1372-1376, 2006. <http://dx.doi.org/10.1590/S010040422006000600037>

UNITED STATES. Environmental Protection Agency - USEPA. Determination of glyphosate in drinking water by direct-aqueous-injection HPLC, post column derivatiozation, and fluorescence detection. 2013. Available in: http://water.epa.gov/scitech/methods/cwa/bioindicators/upload/2007_11_06_methods_ method_547.pdf. Access in May 2014. 